\title{
MicroRNAs Encoded by Virus and Small RNAs Encoded by Bacteria Associated with Oncogenic Processes
}

\author{
Erika Nallely Orendain-Jaime ${ }^{1}$, Nicolás Serafín-Higuera ${ }^{2} \mathbb{D}$, Ana Gabriela Leija-Montoya ${ }^{3} \mathbb{D}^{\text {, }}$ \\ Gustavo Martínez-Coronilla ${ }^{3}$, Misael Moreno-Trujillo ${ }^{4}$ (D) Fausto Sánchez-Muñoz ${ }^{5}$, Armando Ruiz-Hernández ${ }^{3}$ \\ and Javier González-Ramírez ${ }^{1, *}$
}

check for updates

Citation: Orendain-Jaime, E.N.; Serafín-Higuera, N.; Leija-Montoya, A.G.; Martínez-Coronilla, G.; Moreno-Trujillo, M.; Sánchez-Muñoz,

F.; Ruiz-Hernández, A.; González-Ramírez, J. MicroRNAs Encoded by Virus and Small RNAs Encoded by Bacteria Associated with Oncogenic Processes. Processes 2021, 9, 2234. https://doi.org/10.3390/ pr9122234

Academic Editors: Jong Kook Park and Chung Kwon Kim

Received: 18 November 2021 Accepted: 8 December 2021

Published: 11 December 2021

Publisher's Note: MDPI stays neutral with regard to jurisdictional claims in published maps and institutional affiliations.

Copyright: (c) 2021 by the authors. Licensee MDPI, Basel, Switzerland. This article is an open access article distributed under the terms and conditions of the Creative Commons Attribution (CC BY) license (https:/ / creativecommons.org/licenses/by/ $4.0 /)$.
1 Facultad de Enfermería, Universidad Autónoma de Baja California, Av. Álvaro Obregón y Calle “G” S/N, Col. Nueva, Mexicali 21100, BC, Mexico; eorendain@uabc.edu.mx

2 Facultad de Odontología, Universidad Autónoma de Baja California, Zotoluca s/n, Fracc. Calafia, Mexicali 21040, BC, Mexico; nserafin@uabc.edu.mx

3 Facultad de Medicina Mexicali, Universidad Autónoma de Baja California, Centro Cívico, Mexicali 21000, BC, Mexico; gabriela.leija@uabc.edu.mx (A.G.L.-M.); gustavoj@uabc.edu.mx (G.M.-C.); armando.ruiz.hernandez@uabc.edu.mx (A.R.-H.)

4 Departamento de Cuidados Intensivos, Hospital de Gineco-Pediatría \#31, Instituto Mexicano del Seguro Social, Av. Sebastián Lerdo de Tejada S/N, Col. Nueva, Mexicali 21100, BC, Mexico; drmimotru@gmail.com

5 Departamento de Inmunología, Instituto Nacional de Cardiología, Juan Badiano No. 1, Col. Sección XVI, Tlalpan 140080,DF, Mexico; sanchezmunozfausto@gmail.com

* Correspondence: javier.gonzalez.ramirez@uabc.edu.mx; Tel.: +52-(686)-905-8257

Abstract: Cancer is a deadly disease and, globally, represents the second leading cause of death in the world. Although it is a disease where several factors can help its development, virus induced infections have been associated with different types of neoplasms. However, in bacterial infections, their participation is not known for certain. Among the proposed approaches to oncogenesis risks in different infections are microRNAs (miRNAs). These are small molecules composed of RNA with a length of 22 nucleotides capable of regulating gene expression by directing protein complexes that suppress the untranslated region of mRNA. These miRNAs and other recently described, such as small RNAs (sRNAs), are deregulated in the development of cancer, becoming promising biomarkers. Thus, resulting in a study possibility, searching for new tools with diagnostic and therapeutic approaches to multiple oncological diseases, as miRNAs and sRNAs are main players of gene expression and host-infectious agent interaction. Moreover, sRNAs with limited complementarity are similar to eukaryotic miRNAs in their ability to modulate the activity and stability of multiple mRNAs. Here, we will describe the regulatory RNAs from viruses that have been associated with cancer and how sRNAs in bacteria can be related to this disease.

Keywords: microRNA; small RNAs; oncogenesis; viruses; bacteria

\section{Introduction}

In addition to RNAs that encode proteins, different types of genes produce RNAs that are not translated into proteins and are called noncoding RNAs (ncRNAs). All the functions of ncRNAs are still unknown. However, it has been shown that many of them can play essential functions in the regulation of transcription and translation. Moreover, they have even been identified as playing important roles in normal physiological processes and some human diseases [1,2].

NcRNAs have been divided according to their size. RNAs with a size of less than $200 \mathrm{nt}$ are classified as small noncoding RNAs (sncRNA), these include small interfering RNAs (siRNA), miRNA, and RNA that interact with piwi (piRNA). NcRNAs with a size greater than $200 \mathrm{nt}$ are classified as long noncoding RNA (lncRNA) [3]. 
Among the most important sncRNAs are miRNA, piRNA and siRNA [1], which are single stranded molecules of approximately 18-22 nt and 20-24 nt in length, respectively. Both are derived from the cut of long stemmed dsRNA loop precursors. However, sRNAs other than miRNAs have been identified and characterized as not derived from stem loop precursors [4].

The discovery of miRNAs caused many researchers to study them in depth, and it has generated much information to flow. In this regard, there is currently an important collection of information available, which, over time, has allowed researchers to understand the relationship between miRNAs and both normal and pathological biological processes. Unfortunately, there is a long way to go, as there are elements that are not yet fully understood. MiRNAs were first described as posttranscriptional gene regulators in eukaryotic hosts. However, virus encoded miRNAs were later discovered. It is now clear that various families of viruses, most with DNA genomes, but some with RNA genomes, encode miRNA [5], in Figure 1 we can see a diagram that illustrates the biogenesis of miRNAs.

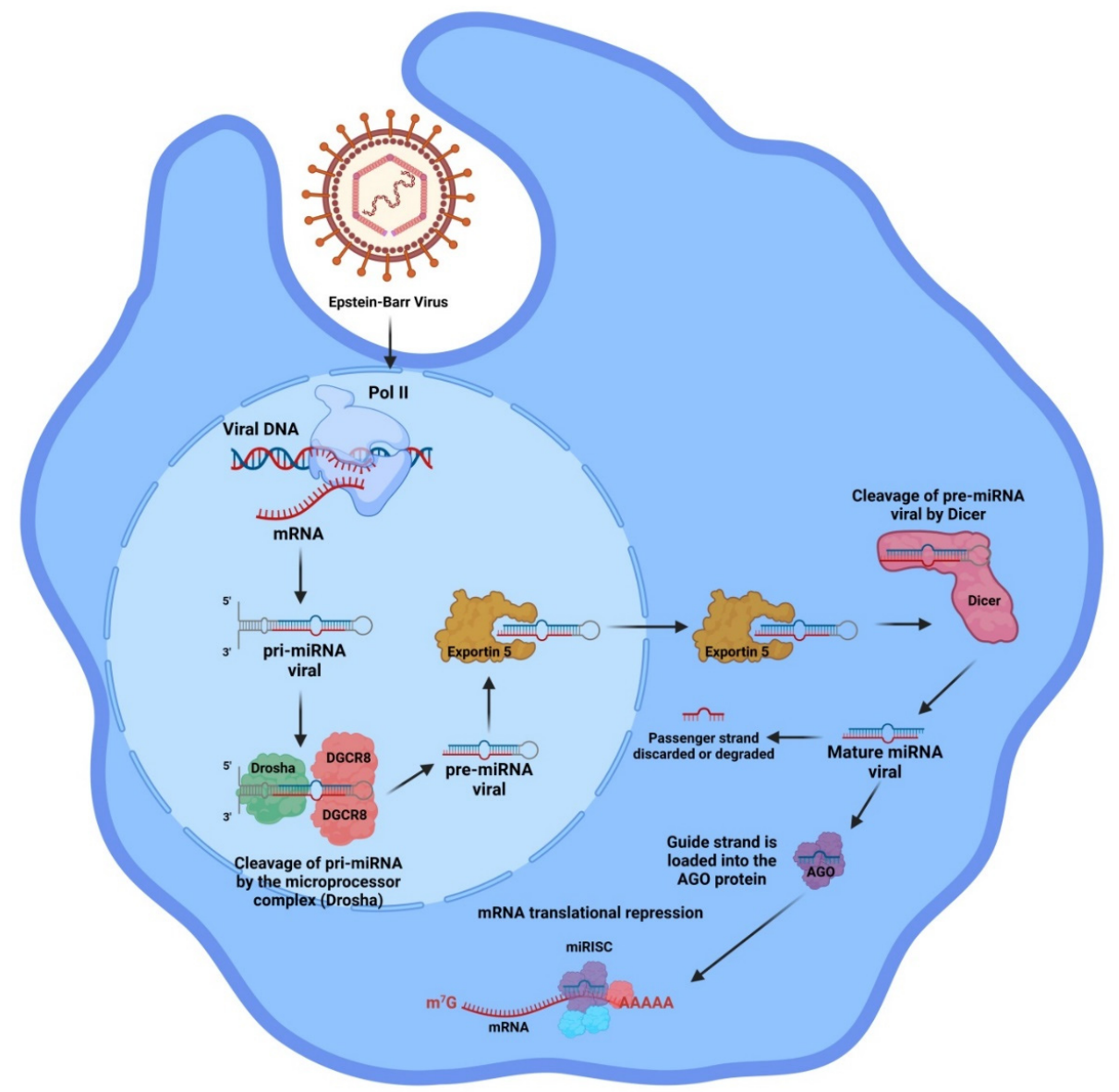

Figure 1. The biogenesis of miRNA. The miRNAs are synthesized through a multistep process. First, the RNA polymerase II (mainly) transcribes a structured primary miRNA (pri-miRNA) in the nucleus. Then, the pri-miRNA is processed into the precursor of miRNAs (pre-miRNAs) by the microprocessor complex, which is structured by the RNase III enzyme Drosha and the protein DGCR8. The pre-miRNAs are hairpins of $\sim 70 \mathrm{nt}$, which are recognized and transported to the cytoplasm by Exportin 5. In the cytoplasm, the pre-miRNA is cleaved by the RNase III enzyme Dicer, which yields a mature-miRNA duplex. Finally, he mature miRNA is loaded within the AGO protein. This structure forms part of the miRISC, which induces mRNA translational repression by binding the 3' untranslated region of the mRNA target. miRNA: microRNA; DGCR8: DiGeorge syndrome critical region 8; AGO: Argonaute protein; miRISC: miRNA-induced silencing complex.

In addition, sRNAs play an important role in the regulation of gene expression in bacteria. RNAs involved in the regulation of transcription are divided into cis and trans. 
Cis-encoded RNAs are encoded by the same genomic locus as their target mRNA and reside in the transcript they regulate (riboswitches), or are derived from the opposite strand (antisense RNAs). In contrast, trans RNAs are encoded elsewhere in the genome and they require the RNA chaperone Hfq to perform their function [6].

Furthermore, sRNAs are highly structured, contain multiple loops, and behave similarly to miRNAs in that they can bind to mRNA targets to regulate gene expression, but they have also been shown to be capable of modifying protein function, mimicking the secondary structures of other nucleic acids. Another difference with miRNAs is that their size ranges from $\sim 50$ to 450 nucleotides (nts), while miRNAs are approximately $22-25 \mathrm{nts}$ long [7], in Figure 2 we can see a diagram that illustrates the biogenesis of sRNAs.

A)

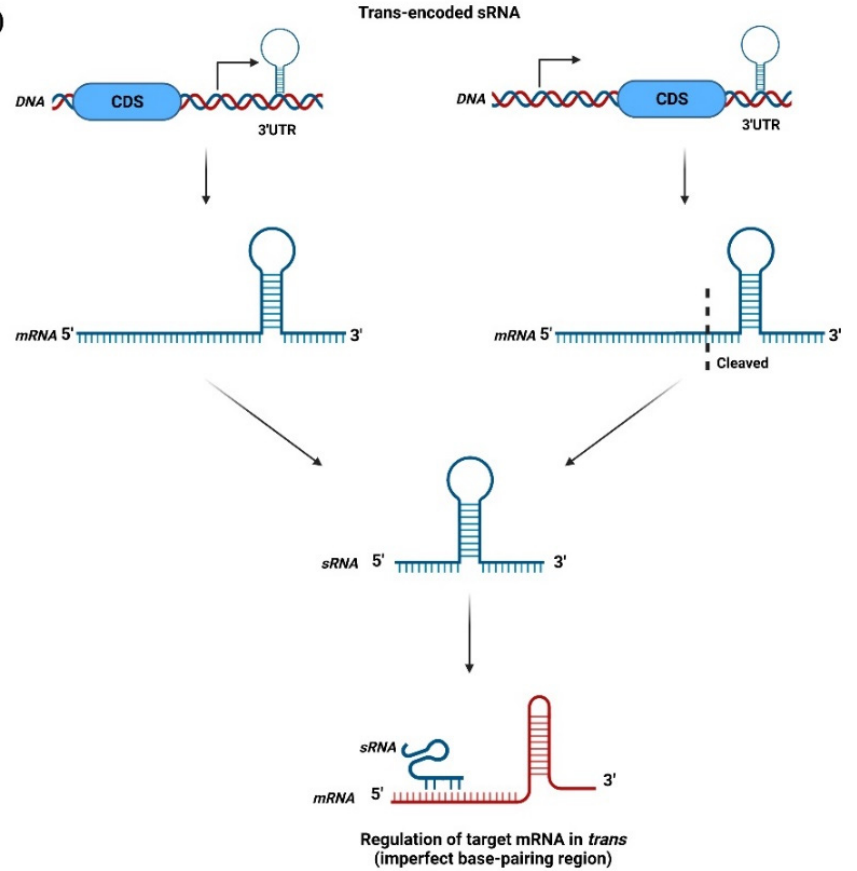

B)

Cis-encoded sRNA
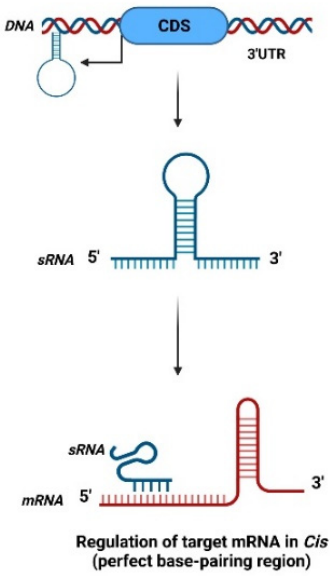

Figure 2. The biogenesis of sRNA from bacterial UTRs. The sRNAs could be either cis- or transencoded. (A) The trans-encoded sRNAs can be found in the 3' UTR region and are transcribed from their promoter in the upstream coding sequence or by internal processing of mRNA containing the sRNA. Moreover, trans-encoded sRNAs form an imperfect base-pairing region with their target mRNA because these genes are separate from each other. Thus, there is no overlap between them. (B) The cis-encoded sRNAs overlap in the genes containing sRNAs but are localized on different strands. Moreover, these sRNAs form a perfect base-pairing region with target mRNA. CDS: coding sequence; sRNA: small RNA; UTR: untranslated region.

It is known that cancer affects people of all ages, and, according to the World Health Organization, it is responsible for one in every six deaths, which makes it the second leading cause of mortality worldwide [8]. Studies have suggested that miRNAs and sRNAs are involved in the development of all types of cancer.

In this review, we will describe regulatory RNAs from viruses and bacteria that have been associated with cancer and how these RNAs (miRNAs in viruses and sRNAs in bacteria) can be related to proliferative processes.

\section{Virus}

Of the 14 million cancer cases diagnosed annually [9], 12-15\% of them are attributed to oncogenic virus infections [10,11], and, despite being a high value, this is considered an underestimated value $[8,12]$. Currently, seven viruses exist that cause oncogenic processes in humans, such as the Epstein-Barr virus (EBV), the hepatitis B virus (HBV), the human T lymphotropic virus type 1 (HTLV-1), human papilloma virus (HPV), hepatitis $C$ virus (HCV), human herpes virus type 8 (HHV-8 or associated with Kaposi's Sarcoma) and the 
most recent discovered to date, the Merkel cell polyomavirus (MCPyV) $[10,13,14]$. Besides, viruses that transform cells into tumors are called oncoviruses [15]. These viruses can cause the alteration of the properties of cells, for example, by inducing cell transformation, which generally includes loss of growth control, growth independent of the anchor, ability to invade the extracellular matrix, loss of differentiation, and immortalization [16].

The mechanisms used by the viruses to induce these changes can be divided into direct and indirect mechanisms. The tissue damage caused by immune cells and chronic inflammation is involved in the transformation of the tumor formation, which is considered an indirect mechanism. Direct mechanisms include the deregulated expression of cellular oncogenes and tumor suppressor genes that, in turn, influences the integration of the viral genome into the host genome [14]. In this way, viruses implement a capable environment for their replication in the host cell through various forms, such as subsistence, proliferation, and transmission, promoting the risk of malignancy associated with viral infection $[10,12]$. Moreover, viruses can lead to the perpetuation of persistent infection with the ability of not being identified by the host's immune system, favoring the possibility of the carcinogenic process $[10,14]$. Among these strategies, the viruses often use the miRNAs to regulate their own gene expression or to influence the host's gene expression, leading to carcinogenic processes. Furthermore, miRNAs represent an abundant class of sncRNAs, which participate in interference and silencing mediated by interfering RNAs (RNAi). The RNAi pathway generates siRNAs or miRNAs from long double stranded stretches of RNA or RNA hairpins, respectively [17].

EBV was the first virus described with a tumor effect, and its infection is an etiological factor in various epithelial and lymphoid neoplasms [18]. EBV was the first neoplastic virus of which the miRNAs encoded by a virus were described and is currently the most characterized $[19,20]$. Current evidence shows that miRNAs participate in various physiological and pathological processes, including their function as crucial players in the onset and progression of cancer $[18,21]$. However, other viruses share similar host attack methods for tumor development. In this part, beyond focusing on reviewing each miRNA produced by oncogenic viruses, we will describe these similar mechanisms in miRNAs from oncogenic viruses with some examples.

\subsection{Immune Evasion}

Viral infection is not synonymous with disease, many viral infections are subclinical (asymptomatic, unapparent), while others give rise to a disease of varying severity that is usually accompanied by characteristic clinical signs in the host. The determinants of host resistance/susceptibility are often multifactorial and include not only a variety of host factors, but also environmental [22]. In addition, when a virus enters the host, it faces the innate immune system. This system uses multiple mechanisms to detect invading viruses. In general, conserved microbial structures are identified. These structures are known as pathogen associated molecular patterns (PAMP), which can be detected by pattern recognition receptors (PRRs) of the innate immune system, resulting in the activation of downstream signaling pathways that then elicit an effective antimicrobial response [23]. In this way, viruses have evolved to avoid many barriers placed by the immune response, having developed mechanisms that allow them immune evasion. These mechanisms include infections without the expression of immunogenic proteins, replication in cells of the immune system, or subversion of the host's innate and adaptive immunity, among others [22]. This may explain why immunosuppressed populations are particularly susceptible to developing different types of cancer [24]. Through these mechanisms, the viruses try to maintain a persistent infection, hiding from the immune system, which is compatible with carcinogenic processes [14]. Moreover, it has been observed that viruses that take advantage of miRNAs have important immunomodulatory functions, of both the innate and adaptive immune responses, allowing the virus to enter a latent phase and not be detected by the immune system, increasing the risk of cancer development [10]. 
Viral miRNAs seem to have a special performance in the spread of the virus, since they can generate multiple strategies to evade the immune system [10]. The adaptation, regulation of the transcriptional machinery, and the use of the latent phase of its life cycle so as not to be detected by the host's immunity, are some mechanisms used by viruses [14,25].

This is not surprising, since miRNAs play a key role in the post-transcriptional regulation of almost all the regulatory pathways of cellular genes. In this way, it has been found that several viruses encode miRNAs that directly downregulate the expression of innate immune factors, including proteins involved in promoting apoptosis and recruiting immune effector cells. However, the activity of viral miRNAs also downregulates host's miRNAs to enhance their replication [26]. Next, we will explain the direct mechanisms used by the different miRNAs produced by the virus for immune evasion that help the cancer process.

\subsubsection{Epstein-Barr Virus}

Epstein-Barr virus (EBV) was discovered in cultured tumor cells derived from a Burkitt lymphoma (BL) biopsy taken from an African patient in 1964. Thus, this virus has more than 50 years of research [27]. In 2004, the first EBV encoded miRNAs were identified, and around 48 EBV encoded miRNAs have been discovered so far. These miRNAs have been divided into three groups: the BART region is subdivided into subgroups 1 and 2, and the BHRF1 group [28,29].

EBV belongs to the herpesviruses family and it is known that herpesviruses are characterized by presenting long term infections in their host. EBV has developed mechanisms to remain undetectable by the immune system. These mechanisms involve restricted gene expression, epigenetic control of the viral-host gene, expression control, and translation. To achieve this, EBV uses (as well as other viruses) miRNAs to regulate its own gene expression and the inhibition of the production of its proteins and those of the host, allowing it to go unnoticed within infected cells [5]. For example, EBV can maintain infection, preventing the recognition of natural killer (NK) cells through miR-BART2. This miRNA reduces the expression of the NK receptor activating ligand MICB. When a cell suffers "attacks" such as a viral infection, the cell can induce the expression of receptors such as MICA. These are recognized by activation receptors such as NKG2D that are present in NK cells. This activates NK cells and kills these transformed and virus-infected cells in a direct way [30].

In addition, EBV has a family of miRNA called BARTs (miR-BART2, miR-BART4, miRBART5, miR-BART18, and miR-BART22). These miRNAs can exert destructive activity by inducing cytokines capable of blocking the immune response during EBV induced carcinogenesis. This was described in a study where it was found that the presence of these miRNAs is associated with a significant and specific positive regulation of PD-1, PD-L1, IL-10 and TGF- $\beta 1$ [31]. The programmed cell death receptor 1 (PD-1) is one of the crucial molecules of the immune checkpoint and is expressed mainly in mature cytotoxic T lymphocytes in peripheral tissues and the tumor microenvironment. PD- 1 signaling is mediated by its two ligands, PD-L1 and PD-L2, which are expressed primarily by cancer cells, leading to immune tolerance [32]. In addition, it is known that IL-10 influences cell proliferation, angiogenesis and inflammatory response [33]. TGF-B1 has been associated with the fact that when elevated levels of TGF- $\beta$ are produced, a functional central TGF- $\beta$ machinery is maintained to promote more aggressive malignant phenotypes [34].

MiR-BART6-3p, another EBV encoded miRNA, acts in Burkitt's lymphoma through the interaction with mRNA of IL-6 receptors and Phosphatase and tensin homologue deleted on chromosome 10 (PTEN). IL-6 receptor participates in processes such as the response to host pathogens. PTEN is found inactive in glioblastomas, melanomas, endometrial, prostate, colon, and bladder cancers, and in lung and breast cancer, the PTEN expression was reduced $[35,36]$. In vitro functional studies, showed that the expression of miR-BART6-3p is inversely related to the receptor subunits of PTEN and IL-6, resulting in the evasion of the host's immune response [35]. 
On the other hand, BHRF1-3 is a miRNA that also participates in the direct immune evasion mechanisms carried out by EBV. This miRNA participates in the modulation of the CTL cytokine pathway through the regulation of mRNA of the CXCL11 cytokine. CXCL11 is a chemoattractant cytokine that plays a crucial role in the transendothelial and interstitial migration of lymphocytes during inflammation induced by IFN in many cells, including endothelial cells $[37,38]$. The evidence indicates that competition mechanisms exist through the viral miRNA against the host's miRNA, resulting in direct cellular changes in their genes. Therefore, EVB miRNAs have an important impact, by blocking the host's cytokine response and evading immune surveillance.

\subsubsection{Human Herpes Virus (HHV-8/KSHV)}

Another oncovirus of the Herpesviridae family is human herpesvirus 8 (HHV-8), also called Kaposi's sarcoma associated herpesvirus (KSHV). This virus coevolved with human populations. However, it is currently only common in sub-Saharan Africa, around the Mediterranean Sea, parts of South America, and in some ethnic communities [39]. This virus has been associated as the etiological agent of multiple types of cancers, the best known being Kaposi's sarcoma, also occurring in primary effusion lymphoma (PEL) and in a rare lymphoproliferative disorder, multicentric Castleman's disease (DCM) [40].

Twenty-five mature miRNAs are encoded by HHV-8. These miRNAs are expressed during latency and many of them can be detected (some are even induced) during lytic infection [41,42]. Although the production of these miRNAs is known, their functions are still largely unknown. However, all these miRNA genes cluster together and are under the control of the latent kaposin promoter (LTd). Most of the miRNA genes are intronic, located between the kaposin sequence and the open reading frame (ORF). However, the miRNAmiR-K10, is located within the kaposin ORF, and miR-K12 is located at the extreme $3^{\prime}$ of the kaposin gene $[43,44]$.

On the other hand, KSHV encoding miRNAs can participate in the evasion and modulation of the immune system by preventing apoptosis and contributing to tumorigenesis. Therefore, they are fundamental in viral pathogenesis by presenting different functions depending on the type of cells that are infected [40]. Moreover, KSHV evades the immune response by modulating cytokine activity and inhibiting the innate response through a lower inflammatory response. The above is due to attenuating type 1 interferon signaling by miR-K12-1 activity. In fact, when this miRNA is overexpressed, viral survival is favored [41,45]. In addition to attenuating type 1 interferon, miR-K12-1 and other miRNAs negatively regulate the stress induced immune molecule MICB during infection, to prevent NK cell induced death [30], a strategy that also uses EBV.

\subsection{Promotion of Tumorigenesis}

Tumorigenesis is the obtaining of malignant properties in normal cells, which mainly include dedifferentiation, rapid proliferation, metastasis, avoidance of apoptosis and immunosurveillance, etc. These changes confer a phenotypic cell advantage, resulting in the clonal expansion of cells. When these cells express these phenotypes, they will eventually undergo another advantageous alteration, once again resulting in clonal expansion $[46,47]$.

It is known that viruses can contribute to oncogenesis through strategies such as miRNAs that target host mRNA. Viruses can promote a hyper proliferative state, upregulating host miRNAs to stimulate the growth of infected cells, as well as being able to sequester miRNAs hosts that act to suppress tumors [13]. Next, we will review some miRNAs produced by viruses that help the tumorigenesis process.

\subsubsection{Epstein-Barr Virus (EBV)}

Several EBV encoded miRNAs can affect caspase production. These proteins are proteolytic enzymes that play an important role in the control of cell death (apoptosis). The caspase function has been known since proteins such as ced-3 were identified. This protein, a homolog of caspases, participates in cell death during the development of the 
nematode Caenorhabditis elegans; so far, 18 caspases have been named in mammals [48]. Moreover, it is known that caspase 3 can be regulated through miRNAs encoded by EBV, including miR-BART1, miR-BART2, miR-BART3, miR-BART4, miR-BART7, miR-BART8, and miR-BART22. [18]. In HEK293T cells it was demonstrated that caspase 3 is a direct target of the BART family miRNAs, which could affect apoptosis and, this way, promote malignancy [49]. On the other hand, caspase 9, which plays a role in the initiation of caspase cascades, can also be regulated by miRNAs of the BART family. Due to indirect effects, miR-BART15-3p can affect BRUCE protein, which to bind to pro-caspase-9 and inhibit its cleavage [50]. When this occurs, apoptosis is partially increased, inhibiting the translation of BRUCE mRNA, the authors propose that it can provide a favorable microenvironment for the growth of EBV associated tumors [51].

BART miRNAs can also regulate proteins that interact with each other, such as the pro-apoptotic proteins PUMA, BIM, and BAD [52]. PUMA, also known as BCL-2 binding component 3 (BBC3), binds to all antiapoptotic members [53], and can be suppressed by miR-BART5. This activity has been demonstrated through both in silico and in vivo experiments (overexpression and loss of function) [54]. Regarding BIM protein, this protein is a target of multiple miRNAs of the BART family, and through microarrays of epithelial cancers infected with EBV, a small decrease in BIM mRNA was noted, but this effect was not observed when detected using RT-qPCR. Therefore, it was thought that the downregulation of BIM occurred mainly post-transcriptionally. In this sense, experiments were carried out that revealed that BIM protein levels in cells were affected by several EBV encoded miRNAs, including: miR-BART11, miR-BART3, miR-BART9, miR-BART11 and miR-BART12, particularly, miR-BART9, miR-BART11 and miR-BART12 downregulated strongest the expression of BIM [55]. Finally, BAD, an initiator of cell death that constitutes a critical control point in apoptosis after cell damage, can be inhibited by miR-BART20-5p. The above was demonstrated by carrying out experiments that found that BAD is a direct target of miR-BART20-5p, resulting in the decrease of the expression of BAD mRNA and protein. Thus, it has been suggested that miR-BART20-5p contributes to tumorigenesis in gastric carcinoma that has been associated with EBV [56].

On the other hand, TOMM22 is a translocase protein that belongs to the TOMM complex that assists in the translocation of proteins into the mitochondria, and is essential to stabilize the integrity of the import pore, in addition, the absence of TOMM22 has been shown to result in the specific apoptosis of hepatocytes [57]. This protein is also targeted by EBV miRNAs and miR-BART16 [58]. In addition, the death agonist protein of the domain that interacts with BH3 (Bid), which participates as a proapoptotic protein [59], is inhibited by miR-BART4-5P. The inhibition was reported in silico and was verified by experiments that showed that the transfection of ebv-miR-BART4-5p resulted in the suppression of Bid. Thus, it was proposed that the expression ebv-miR-BART4-5p controls the level of the proapoptotic protein Bid [60].

Another protein that participates in apoptosis is TAX1BP1. In addition to participating in apoptosis, it serves as an adapter molecule, recruits ligases, cooperates in signaling as well as induces IFN [61], and it has been shown that TAX1BP1 mRNA is direct target of miR-BART15-3p, which binds to the 3'-UTR region of TAX1BP1 mRNA [62].

The transforming growth factor $\beta$ (TGF- $\beta$ ) and Wnt pathways are involved in the induction of tumorigenesis, and are regulated by EBV miRNAs. TGF- $\beta 1$, TGF- $\beta 2$ and TGF- $\beta 3$ participate in several aspects of tumor development through two transmembrane serine-threonine kinase receptors (TGF $\beta R 1$ and TGF $\beta R 2$ ) and its signaling can promote or inhibit tumorigenesis [63]. Wnt is a family of signaling proteins that serve as key mediators during embryonic development. The Wnt pathway has been associated with cancer since it was discovered that the activation of Wnt1 resulted in mammary hyperplasia and tumors. Currently, it is known to be associated with colon rectal cancer in humans [64]. Both pathways were related to EBV miRNAs. For example, in a study, nasopharyngeal cancer samples were analyzed through microarrays, using bioinformatics tools such as: gene ontology (GO) and the pathway analysis of the Kyoto Encyclopedia of Genes and Genomes 
(KEGG), it was found that several EBV miRNAs are upregulated (miR-BART3 and miRBART5) and their target genes p53, TGF- $\beta$, and the Wnt signaling pathway to modulate apoptosis [65].

We conclude that EBV miRNAs can modulate tumor cell proliferation through various mechanisms, including silencing tumor suppressor genes and, thus, regulating cell apoptosis, establishing a means of tumor promotion and leading to carcinogenesis.

\subsubsection{Human Herpes Virus (HHV-8/KSHV)}

KSHV miRNAs have reached great importance due to the influence that they have on tumorigenesis. Once KSHV infects the individual, the cell cycles of the host cells are deregulated by the genes encoded by KSHV [66,67]. For example, KSHV induces the progression of the host's cell cycle and its growth, promoting the transformation of infected cells. The transformation of affected cells and their oncogenesis carries an important ability to prevent apoptosis. For example, a joint activity seen between miRNAs miR-K12-1, miR-K12-3 and miR-K12-4-3p is to suppress caspase 3 by joining to its 3'UTR and, thus, reducing apoptosis in infected cells, altering their functions without killing them [68].

The weak inducer of apoptosis similar to tumor necrosis factor (TWEAK) is another factor involved in apoptosis and is regulated by KSHV miRNAs. Previously, TWEAK was identified as a member of the tumor necrosis factor (TNF) superfamily and as capable of inducing cell death in certain cancer cell lines. Studies have demonstrated that the receptor of TWEAK (TWEAKR) is directly regulated by miR-K10a, resulting in being effective in protecting cells from TWEAK-induced apoptosis [69]. It had been reported that miR-K10a could also target the Bcl-2-associated transcription factor 1 (BCLAF1). This protein was initially identified to interact with the Bcl-2 family and has been shown to play a key role in apoptosis [70]. In 2009, BCLAF1 was identified as a target of KSHV miR-K12-5, miR-K -9, and miR-K $-10 \mathrm{~b}$, using a series of microarrays [71].

Among the previous miRNAs, miR-K1 plays an important role in tumorigenesis. miR-K1 targets the cell cyclin-dependent kinase inhibitor (p21), resulting in affecting p53 activity. Furthermore, p21 is involved as a vital regulator of cellular functions, including activity as a tumor suppressor, although it has also been given an important role in tumor development through p53-dependent and independent pathways. Thus, p21 is implicated in the response to many cancer treatments [72,73]. Finally, in a bioinformatics analysis it was found that Rbl2 is a target of miR-K12-4-5p. Rbl2 belongs to the Rb family, which participates in the cell cycle, as well as vigilance in cell differentiation [74]. Summary of miRNAs function reviewed in this work are indicated in Table 1.

Table 1. Summary of miRNAs encoded by viruses and the molecules they affect.

\begin{tabular}{|c|c|c|c|}
\hline miRNAs BART & Target Gene & Function Target Gene & References \\
\hline EVB-miR-BART2 & BIM & $\begin{array}{l}\text { BIM plays a role in tumor cell biology, } \\
\text { regulating the tumorigenesis through } \\
\text { activities such as tumor suppressor, tumor } \\
\text { metastasis and tumor cell survival }\end{array}$ & $\begin{array}{c}\text { (Nachmani, Stern-Ginossar, Sarid y } \\
\text { Mandelboim, 2009) }\end{array}$ \\
\hline $\begin{array}{l}\text { EBV-miR-BART-2, } 4, \\
5,18 \text { y } 22\end{array}$ & $\begin{array}{l}\text { PD-1, PD-L1,IL-10 } \\
\text { and TGF- } \beta 1\end{array}$ & $\begin{array}{l}\text { The PD-1/PD-L1 pathway is an inducer of } \\
\text { immune suppression against cancer. } \\
\text { IL-10 is a cytokine with an important } \\
\text { regulatory role in the immune response, } \\
\text { which influences cell proliferation, } \\
\text { angiogenesis, and inflammatory response. } \\
\text { TGF-B1 is a protein from the family of } \\
\text { growth factors, it has a very important role } \\
\text { in the regulation of proliferation and } \\
\text { differentiation of various cell types, as well } \\
\text { as in the immune response }\end{array}$ & $\begin{array}{c} \\
\text { (Pandya et al., 2015) } \\
\text { (X. Wang et al., 2020) } \\
\text { (Medina-Ortega, López-Valencia, } \\
\text { Mosquera-Monje, Mora-Obando, \& } \\
\text { Dueñas-Cuéllar, 2017) } \\
\text { (Velapasamy, Dawson, Young, } \\
\text { Paterson y Yap, 2018) }\end{array}$ \\
\hline
\end{tabular}


Table 1. Cont.

\begin{tabular}{|c|c|c|c|}
\hline miRNAs BART & Target Gene & Function Target Gene & References \\
\hline EBV-miR-BART6-3p & IL-6 and PTEN & $\begin{array}{l}\text { IL-6 is part of the "inflammatory cascade", } \\
\text { which consists of the periodic activation of } \\
\text { different pathways of the immune response } \\
\text { in an orderly manner. } \\
\text { PTEN is a known tumor suppressor. }\end{array}$ & (Ambrosio, et al., 2014). \\
\hline $\begin{array}{c}\text { EVB-miR-BART 1, 2, } \\
3,4,7,8 \text { y } 22\end{array}$ & Caspase 3 & $\begin{array}{c}\text { Proteins with proteolytic enzymatic activity } \\
\text { widely known for their role in the control } \\
\text { of cell death. }\end{array}$ & (M. Wang, et al., 2019). \\
\hline KSHV-miR-K12-1 & Interferon Type 1 & $\begin{array}{l}\text { IFN-1 helps regulate the activities of the } \\
\text { immune system, such as antiviral, } \\
\text { antiproliferative, pro-apoptotic and } \\
\text { immunoregulatory effects. }\end{array}$ & (Nachmani, et al., 2009). \\
\hline
\end{tabular}

\section{Bacteria}

Although the role of bacteria in the development of neoplasms has not been elucidated, it is known that there is a link between bacterial species and cancer. Bacteria can influence the immune response to stimulate tumor cells. In addition to the induction of inflammation, bacteria can participate in cancer development [75], affecting important cellular pathways such as the maintenance of proliferative signaling, avoiding growth suppressants, resisting cell death, allowing replicative immortality, etc. [76]. Of all reported bacteria, the two bacteria most commonly associated with cancer are Helicobacter pylori and Fusobacterium nucleatum [77].

\subsection{Small RNAs Encoded by Bacteria}

Despite the thousands of miRNAs that have been reported in eukaryotes and viruses, until 2013 it was considered that they did not exist in the bacterial kingdom [78,79]. In Streptococcus mutans, Escherichia coli and mycobacteria miRNAs have been identified through modern sequencing techniques [80-82], however, their importance or function in fundamental processes of bacteria has not been ubiquitously recognized.

Other ncRNAs have been shown to carry out a similar function in bacteria. These are small RNAs that act by base-pairing with target mRNAs with which they share limited or extended complementarity, or by modulating the activity of proteins. In some cases, they can mimic other nucleic acids. Mechanisms insights into how RNAs bind to mRNAs and proteins, how they compete with each other, and how they interact with ribonucleases are active areas of discovery [83]. For this reason, in this second part small RNAs present in bacteria associated to cancer will be reviewed and the possibility of their participation in the promotion of tumorigenic process discussed.

\subsection{Mechanisms of Action of Bacterial Small RNAs}

Small RNAs are short RNA species that can regulate the expression of proteins in cis or trans forms. In bacteria, the possible action mechanisms of sRNA are: the stabilization/destabilization of the mRNA, the conduction of the target mRNAs to degradation, or direct binding to regulatory proteins. As a result, bacteria can adapt to changes in environmental conditions when it enters the host or passes into a free state, and this is achieved by interacting with host genes and reducing the immune system of the guest [84].

\subsubsection{Stabilization/Destabilization of mRNA}

Small RNAs can carry positive and negative actions in bacteria, which are rarely seen in eukaryotes. In this way, these small RNAs can act as activators of mRNA [85]. Several small bacterial RNAs regulate gene expression at the post-transcriptional level. These small RNAs bind to an Hfq protein and subsequently bind to target RNA through RNA base-pairing interactions, to regulate the expression. Hfq is a very abundant and 
highly conserved protein that has been implicated in a series of RNA mediated events. It is believed to contribute to structural changes in some RNAs and modify the stability of others. [86].

\subsubsection{Degradation of Regulatory Proteins}

Small RNAs that can bind to Hfq are small RNAs that are functionally analogous to eukaryotic miRNAs. These RNAs are generally transcribed under specific physiological conditions, act by pairing with target mRNAs and regulate their translation. They are known to achieve this through the help of Hfq, which facilitates the pairing and stabilization of RNAs, the result being the rapid degradation of the target mRNAs [87].

\subsection{Bacteria Associated to Human Cancers}

Increasing numbers of bacteria have been associated with human cancers and studies of the human microbiome have diluted several complex interactions between prokaryotes and their hosts [76]. Thus far, the two bacteria most commonly associated with cancer are H. pylori and Fusobacterium nucleatum [77], and H. pylori is the only bacteria with clear epidemiological data supporting a causal link with carcinogenesis [76]. Understanding the carcinogenic mechanisms that microorganisms trigger will help provide useful clues for the management, control, and, ultimately, prevention of cancers associated with pathogens [88].

\subsubsection{Helicobacter Pylori}

Long term infection of the stomach with Helicobacter pylori can cause gastric cancer. However, the mechanisms by which bacteria adapt to the stomach environment are poorly understood [89]. It is known that Helicobacter pylori secrete virulence factors, which damage the cell barrier. However, in addition to virulence factors, it has been suggested that ncRNA can regulate the stability of proteins and mRNA, which ultimately leads to growth and bacterial reproduction and use to virulence [90].

sRNA RepG (Regulator of Polymeric G-Repeats)

The regulator of polymeric G-repeats (RepG) is an intergenic sRNA of $87 \mathrm{nt}$, and is highly conserved in Helicobacter pylori strains [91]. In silico analysis, it was predicted that its secondary structure involves two stem loops. It was reported that a U/C-rich region in one of the stem loops is responsible for regulating the expression of Helicobacter pylori chemotaxis receptor tlpB [91]. The molecular mechanism of RepG regulation involves the interaction between the U/C rich region of the RepG sRNA and a repeat of guanines (G-repeat) in the tlpB 5' UTR, resulting in decreased protein and mRNA expression of tlpB [91]. The TlpB receptor senses urea gradient from the gastric epithelium and allows attracting Helicobacter pylori to contribute to initial colonization [92]. Additionally, it was reported that this chemoreceptor permits Helicobacter pylori accumulation at gastric damage sites using 3D cell cultures of gastric epithelial cells [93]. In addition, TlpB can sense repellents such as acid $\mathrm{pH}$ and autoinducer 2 (AI-2) [93]. Thus, chemoreceptors, as $\mathrm{TlpB}$, detect signals in a changing gastric environment and permit the making of decisions of navigation by Helicobacter pylori. TlpB expression regulation by RepG could deeply affect the behavior of Helicobacter pylori.

Interestingly, the variations in the length of the G-repeat modulated the levels of repression of TlpB by RepG. Thus, repeats of variable length and regulation of RepG may generate phenotypic variation in Helicobacter pylori, allowing adaption of this pathogen to changing conditions [91]. It was suggested that tlpB is not necessary for the establishment of infection. However, it is also important for the persistence of Helicobacter pylori in the stomach [92], and long term infection has been associated with the development of gastric cancer. Thus, expression modulated by RepG could be important in the adaptation and chronic infection of Helicobacter pylori and, indirectly, could be involved in the promotion of tumorigenesis. However, this has not yet been determined. 


\section{sRNA CncR1 (Cag-Non-Coding RNA1)}

Studies have suggested that the conserved sRNA cag-non-coding RNA1 (CncR1) encoded in the cag pathogenicity island, could regulate the expression of several genes of Helicobacter pylori involved in metabolism, chemotaxis, motility, signaling, translation, transcription, and DNA processing [94]. Moreover, CnCR1 decreases the mRNA expression of flagellar genes (flaB, flgE, fliK and flgB genes), resulting in the decreased motility of Helicobacter pylori in vitro. On the other hand, CncR1 promoted the production of the transcripts sabA (Sialic acid-binding Adhesin) and HP1392 (fibronectin/fibrinogen binding protein), which induced more adhesion of Helicobacter pylori to human gastric adenocarcinoma cell in vitro [95]. Mechanistically, base pairing between CncR1 and different regions of the fliK transcript generates the reduced expression of this flagellar [95]. However, the molecular mechanisms involved in the expression modulation of the others genes were not determined. The interplay between bacterial motility and adhesion to host cells modulated by CncR1 could allow the successful establishment of Helicobacter pylori infection, dissemination, and persistence, which has been reported to favor tumorigenesis.

sRNA NikS (Nickel Regulated sRNA)

Nickel regulated sRNA (NikS), also called HPnc4160, is a trans-acting transcript of approximately $110 \mathrm{nt}$. NikS can inhibit the expression of multiple important factors involved in virulence and colonization of Helicobacter pylori, such as CagA, VacA, OMPs HofC, and the conserved hypothetical protein HPG27_1238/HP1286 with a YceI domain. The suggested molecular mechanism involves the base-pairing among NikS and the translation initiation regions of the target transcripts, resulting in the inhibition of translation initiation [96].

In addition, high nickel concentration can repress NikS expression by binding the nickel responsive transcriptional regulator NikR to NikS promoter [96]. Interestingly, NikS expression is regulated by a promoter containing length variable thymine (T) stretch [96]. This stretch represents a hyper mutable simple sequence repeat (SSR). Diverse strains and isolates of Helicobacter pylori from patients showed variations in the T-stretch length and these variations in length affected the expression levels of NikS, moreover, NikS can modulate the expression of various major virulence and colonization factors. NikS expression regulated by this SSR could promote the increase of phenotypic variability in Helicobacter pylori population, allowing the selection of members better equipped to colonize and adapt to changing conditions $[96,97]$. Thus, variable expression of NikS could allow chronic infection of Helicobacter pylori, which is associated with gastric cancer. Apparently, increased expression of NikS could be beneficial to the host because it negatively regulates the colonization and invasion of Helicobacter pylori. In this sense, recently, it was suggested that NikS can have a potential role carcinogenic. It was reported that T-repeats upstream of coding region were longer in Helicobacter pylori strains derived from patients with cancer than in those derived from non-cancer patient. Longer T-stretch promotes a reduce mRNA expression of NikS and increased expression of Cag which were associated to persistent infection [89].

sRNA sR-2509025 and sR-989262

Helicobacter pylori can secrete outer membrane vesicles (OMVs). It has been shown to be related to host-pathogen communication. Hongxia Zhanga, et al., reported that a great variety of small noncoding RNAs (sncRNA) between 15 and $55 \mathrm{nt}$ can be packaged in Helicobacter pylori OMVs, and these can deliver the sncRNA cargo to host cells [98]. Interestingly, the scnRNA sR-2509025 and sR-989262 from Helicobacter pylori OMVs inhibited the IL-8 expression of human gastric adenocarcinoma cells in vitro [98]. Thus, Helicobacter pylori sncRNAs can disrupt the immune response of the host. Although it has not been proven that these sncRNAs promote tumor development. It is possible that they facilitate the establishment of the chronic infection of Helicobacter pylori, an event that has been associated with gastric cancer. 


\section{sRNA 5'ureB-sRNA}

The 5'ureB-sRNA is a cis-acting antisense sRNA of 292 nucleotides encoded in the $5^{\prime}$ region of noncoding strand from ureB gene. This sRNA negatively regulates the expression and activity of Helicobacter pylori urease [99]. In Helicobacter pylori, urease is an important pathogenic factor required for successful colonization in the acidic stomach environment [100]. Two structural proteins, $\alpha$ and $\beta$ subunits, in the supramolecular assembly of 12 active dimers [ $4(\alpha \beta) 3$ ] compose active Helicobacter pylori urease [100]. Urease seven genes cluster is important in the regulation and activity of this enzyme. The ureA and ureB genes in the cluster encode for structural and catalytic subunits of urease from Helicobacter pylori [101]. The gene expression of urease is induced when the Helicobacter pylori is exposed to low $\mathrm{pH}$ for survival. However, the increase in the production of urease is lethal at a relatively neutral $\mathrm{pH}$. Thus, urease activity should be downregulated at a relatively neutral $\mathrm{pH}$. Moreover, the transcriptional induction of urease genes is mediated mainly by the HP0165-HP0166 two-component system [102].

Mechanistically, under neutral $\mathrm{pH}$ conditions, the protein sensor histidine kinase of Helicobacter pylori (HP0165) is not activated by autophosphorylation. In consequence, its cognate response regulator HP0166 is not phosphorylated. Unphosphorylated HP0166 binds 5'ureB-sRNA promoters and induces its expression. Subsequently, 5'ureB-sRNA binds complementarily to ure $\mathrm{AB}$ mRNA (this transcript is the result of the expression from the ure $\mathrm{AB}$ bicistronic operon encoding ure $\mathrm{A}$ and ureB genes regulated by the Pure $\mathrm{AB}$ promoter). The 5'ureB-sRNA-ureAB mRNA complex results in the truncation of ureAB mRNA, losing most of the ureB transcript region, and reducing urease activity. It is possible that base pairing between the 5'ureB-sRNA-RNAses involved in the generation of the truncated transcript has not been determined. Moreover, it was suggested that 5 'ureB-sRNA could not interfere with translation initiation [99]. On the other hand, acid $\mathrm{pH}$ conditions are perceived by HP0165, resulting in its autophosphorylation and phosphorylation of HP0166. In this form, HP0166 binds the PureAB promoter, increasing the expression of the ureAB mRNA and promoting urease activity [99]. Indirectly, 5'ureB-sRNA could contribute to malignancy, helping to face $\mathrm{pH}$ changing environments and allowing the persistence colonization of Helicobacter pylori in gastric mucosa.

\section{Others sRNAs}

Two intergenic sRNAs, called Natural antisense transcripts 39 (Nat-39) and Nat-67 of 64 and $90 \mathrm{nt}$, respectively, were identified [103]. It was predicted that these sRNAs could act in cis interacting with the transcript of frpB and ceuE genes, since Nat-39 and Nat-67 are encoded in the opposing DNA strand [103]. However, this was not determined experimentally. Summary of sRNAs function reviewed in this section are indicated in Table 2.

Table 2. Summary of sncRNAs encoded by bacteria and target genes.

\begin{tabular}{|c|c|c|c|}
\hline \multicolumn{4}{|c|}{ Helicobacter Pylori } \\
\hline sRNA & Target Gene & Target Gene Function & References \\
\hline RepG & TlpB & $\begin{array}{l}\text { Chemoreceptor that senses urea gradient and } \\
\text { AI- } 2 \text {. }\end{array}$ & (Huang et al., 2015) \\
\hline CncR1 & $\begin{array}{r}\text { FliK } \\
\text { CagA }\end{array}$ & Controls flagella hook length. & (Vannini, et al., 2016) \\
\hline NikS & $\begin{array}{l}\text { VacA } \\
\text { OMPs } \\
\text { HofC } \\
\text { HPG27_1238 } \\
\text { HP1286 }\end{array}$ & $\begin{array}{l}\text { Bacterial internalization, colonization and } \\
\text { epithelial barrier disruption, production of } \\
\text { phosphorylated CagA in host cells. }\end{array}$ & $\begin{array}{c}\text { Eisenbart et al., (2020), Kinoshita-Daitoku } \\
\text { et al., (2021) }\end{array}$ \\
\hline $\begin{array}{l}\text { sR-2509025 } \\
\text { sR-989262 }\end{array}$ & 1111200 & $\begin{array}{c}\text { Cytokine in the host inflammatory response. } \\
\text { Lead to free radical generation and release of } \\
\text { proteolytic enzymes from activated neutrophils, } \\
\text { affecting mucosal integrity. }\end{array}$ & (H. Zhang, et al., 2020) \\
\hline 5'ureB-sRNA & $\begin{array}{l}\text { UreA } \\
\text { UreB }\end{array}$ & $\begin{array}{l}\text { Acid neutralization. Acts to buffer the acidity of } \\
\text { the local environment around the cell. }\end{array}$ & $\begin{array}{l}\text { (Y. Wen, Feng, Scott, Marcus, \& Sachs, } \\
\text { 2007) }\end{array}$ \\
\hline $\begin{array}{l}\text { Nat-39 } \\
\text { Nat-64 }\end{array}$ & $\begin{array}{l}\text { FrpB } \\
\text { ceuE }\end{array}$ & Associated with growth. & {$[104]$} \\
\hline
\end{tabular}




\subsubsection{Fusobacterium Nucleatum}

Fusobacterium nucleatum has been frequently found in samples of colorectal cancer. Thus, it was suggested as a possible risk factor in this cancer [104,105]. Mechanistically, Fusobacterium nucleatum can modulate the inflammatory response, promote infiltration of myeloid cells, and inhibit NK cells activity. Moreover, virulence factors could induce the development the proliferative lesions [105].

The presence of sRNA of Fusobacterium nuleatum has been reported in samples of human colon cancer with a higher expression than in normal tissue. However, the role of these sRNA's has not been determined $[104,106]$. Specific identification and functional analysis of sRNAs of Fusobacterium nucleatum, as well as the possible participation direct or indirect in tumorigenesis, are absent.

\subsection{Bacterial Small RNA's and Cancer Associated Microbiome}

Recently, analyses of microbial sRNA have been utilized to define the composition of the microbial complex community related to cancer, with an emphasis on colorectal cancer $[104,106,107]$. Increased expression of sRNAs from Bacteroides, Bacillus, and Fusobacterium genera was reported in colorectal cancer. Moreover, evaluation of nonhuman sRNAs allowed the identification of overrepresented bacteria in colorectal cancer, such as Fusobacterium, Streptococcus, Veillonella, Haemopilus, Bilophila, Acinetobacter, Phascolarctobacterium, Akkermansia, Escherichia, Enterococcus, Parvimonas, and Anaerococcus, in accordance with previous studies [106]. Another report showed the differential expression of the microbial sRNAs of stool samples from patients with colorectal cancer, adenomas, and from healthy subjects [107]. Regarding these observations, a possible role of microbial sRNAs as biomarkers in colorectal cancer was suggested [105]. Further studies should be focused on the possible molecular mechanisms of bacterial sRNAs in proliferative processes.

\subsection{Importance of the Identification and Characterization of Small RNAs in Bacteria}

Several studies that led to the characterization of bacterial small RNAs have discovered that interaction with host RNAs and proteins may modulate their activities. In recent years, the application of deep RNA sequencing has revealed the presence of hundreds of additional RNA candidates in a wide swath of bacterial species [83]. Nevertheless, more studies that characterize new bacterial RNA species and their interactions in the transcriptional regulatory networks of bacterial species are needed [108]. In order to characterize these sRNAs, several computational or experimental tools to identify regulatory targets of sRNAs have been developed. Thereby, these tools continue to be updated, allowing the identification of new small RNAs codified by bacteria to move toward a more complete understanding of the functioning of bacterial regulatory networks [109]. These regulatory interactions should enable potential targets for synthetic biology, antimicrobials and therapeutics and this is because knowing these networks in the future could help to modulate these circuits in a predictable way [110]. Furthermore, one of the long term goals of synthetic biology is to develop designable genetic parts with predictable behaviors that can be used to implement various cellular functions, hence the discovery of noncoding RNAs is a natural target of synthetic biology [111].

Regarding its possible use as an antimicrobial target, we have to consider that it has been shown that noncoding RNAs can contribute to antibiotic resistance and, therefore, present potential value as pharmacological targets; in fact, it is known that small RNAs modulate tolerance to antibiotics by base pairing with mRNAs that encode important functions for resistance and it is known that bacteria can make changes in their repertoire of RNAs to antibiotics, so regulatory RNAs, including RNAs and their protein interaction partners, such as Hfq, may be useful as targets for antimicrobial chemotherapy [112].

Another way to use this information is to employ small RNAs that regulate genes that favor pathogens in invasion and resistance (Virulence), for example, this can be observed in the work of [113]. This work describes the participation of a S. aureus smallRNA, 
which was used to control virulence genes, and in this work it is shown that an RNA encoded by prophages reduces the pathogenicity of $S$. aureus through the activity of an RNA sponge [113]. These examples show us that the study and utility of the identification and characterization of sRNAs is expanding and will probably be useful at some point in cancer counting therapies.

One last example involves membrane vesicles: these are nanoparticles produced by bacteria with diverse compositions, sizes and biological functions. Classical membrane vesicles are referred to as outer membrane vesicles (OMV) [114]. OMVs can contain biomolecules, such as proteins, DNA, RNA, lipids and lipoproteins, which have been associated with immunomodulating effects on animal cells [114]. These characteristics represent potential applications in the development of vaccines. OMVs have been analyzed as antigens for vaccines with a robust and prolonged protection [115]. Additionally, applications such as immunoadjuvants, cancer immunotherapy agents, drug delivery vehicles, and antibacteria adhesion agents have been described [116]. In this sense, Helicobacter pylori and Fusobacterium nucleatum produce OMVs with the capacity to modulate the inflammatory response of human cells [116-118]. Interestingly, OMVs generated by $\mathrm{H}$ pylori can contain sRNA's that reduce the production of IL-8 by an unknowing mechanism [98]; however, the presence of sRNAs in OMVs produced by Fusobacterium nucleatum has not been analyzed. Future studies should determine and characterize the sRNAs present in OMV's from Fusobacterium nucleatum, to establish possible biological effects in hosts. Importantly, it was suggested that OMVs from $\mathrm{H}$ pylori could be implicated in gastric cancer development [119]; however, it is not known the role of OMVs from Fusobacterium nucleatum in the context of cancer. Thus, signaling by sRNA packed in OMVs and transported out of bacteria associated with cancer must be addressed, since knowledge in this area is lacking and presents potential clinical applications as delivering vectors combined with possible small RNA based therapy.

\section{Discussion and Conclusions}

In the analysis of miRNAs, two techniques have been important to determining the functionality and participation of these in pathologies: the first is the use of computational tools to predict the secondary structure of the precursor of v-miRNAs (pre-v-miRNAs), and the second the sequencing of cloned small RNA molecules [120].

On one hand, it must be said that, although these tools have given good results, the process to be able to accurately identify miRNAs is still a complex and difficult task, which requires the integration of experimental approaches with computational methods [121]. Let us remember that, when a bioinformatics analysis is carried out, these present limitations since there are bottlenecks in the existing algorithms and approaches, since the base pairing of miRNA-mRNA in mammals is not perfectly complementary and only a fraction of the identified motifs are actual binding sites, so the accurate prediction of miRNA targets remains a challenge, however an initial approximation using these tools is currently a high priority [122]. On the other hand, small RNA sequencing (RNA-seq) allows the profiling and analysis of the entire genome of known and novel miRNA variants, and has high sensitivity [123]; however, it has several limitations such, as the interpretation of data possibly being a computational challenge, quantification can be affected by biases introduced during the construction of the cDNA library and the alignment of sequences, and some others, including that it can be quite expensive (this obviously depends on the resources available to the researcher) [124].

These small problems associated with bioinformatics analyses can be solved by implementing evaluations experimentally through in vitro assays to validate and quantify the transcriptional or post-transcriptional effects of the miRNA-target gene interaction, thus, in vivo genetic studies are critical, to determine the occurrence and the biological relevance of miRNA targets under physiological conditions [125]. The coupling of these two techniques with in vivo studies has made it possible to determine that different viruses are linked to oncogenic processes and the underlying mechanisms promoting cancer in- 
clude the activity of viral microRNAs. These regulatory RNAs can modulate host cellular functions as immunological responses, apoptosis, and proliferation.

Concerning the second interest of this review, small RNAs have been recognized as a regulator of a wide range of biological process with clinical relevance, such as antibiotic resistance and pathogenicity. However, information about small RNAs analyzed in bacteria associated to cancer is much reduced and much of the research in this regard has focused on E. coli $[126,127]$. From our viewpoint, there is still much to explore, for example, the targets and molecular mechanisms involved in regulation by sRNA's from Fusobacterium nucleatum are absent. We believe that analyses of these sRNAs must be performed, since Fusobacterium nucleatum has been associated to different diseases, in addition to colon cancer, such as periodontitis, appendicitis, urinary tract infections, endocarditis, respiratory tract infections [128]; moreover, it is important to determine the context of the study or disease, since the expression of sRNAs is highly affected by micro ambient conditions.

Author Contributions: J.G.-R., E.N.O.-J., N.S.-H., A.G.L.-M., G.M.-C., M.M.-T., F.S.-M., A.R.-H. All those mentioned contributed equally to the design and implementation of the review, the analysis and writing of the manuscript. All authors have read and agreed to the published version of the manuscript.

Funding: The writing of this review received no external funding.

Institutional Review Board Statement: Not applicable.

Informed Consent Statement: Not applicable.

Data Availability Statement: Not applicable.

Acknowledgments: The authors thank Adrian Diaz-Couder for the preparation of the figures and critical review of the manuscript.

Conflicts of Interest: The authors declare no conflict of interest.

\section{References}

1. Zhang, P.; Wu, W.; Chen, Q.; Chen, M. Non-Coding RNAs and their Integrated Networks. J. Integr. Bioinform. 2019, 16, 20190027. [CrossRef]

2. Trovero, M.F.; Geisinger, A. Los ARNs no codificantes largos y su vinculación con las patologías testiculares. In Anales de la Facultad de Medicina; Facultad de Medicina, Universidad de la República: Montevideo, Uruguay, 2019; Volume 6, pp. $12-47$.

3. Li, C.H.; Chen, Y. Small and Long Non-Coding RNAs: Novel Targets in Perspective Cancer Therapy. Curr. Genom. 2015, 16, 319-326. [CrossRef]

4. Ledda, B.; Ottaggio, L.; Izzotti, A.; Sukkar, S.G.; Miele, M. Small RNAs in eucaryotes: New clues for amplifying microRNA benefits. Cell Biosci. 2020, 10, 40. [CrossRef] [PubMed]

5. Kincaid, R.P.; Sullivan, C.S. Virus-Encoded microRNAs: An Overview and a Look to the Future. PLOS Pathog. 2012, 8, e1003018. [CrossRef]

6. Westra, E.R. RNA I Small RNAs in Bacteria. In Encyclopedia of Biological Chemistry III, 3rd ed.; Jez, J., Ed.; Elsevier: Oxford, UK, 2021; pp. 580-586.

7. Cardin, S.E.; Borchert, G.M. Viral MicroRNAs, Host MicroRNAs Regulating Viruses, and Bacterial MicroRNA-Like RNAs. Methods Mol. Biol. 2017, 1617, 39-56. [CrossRef]

8. The global challenge of cancer. Nat. Cancer 2020, 1, 1-2. [CrossRef]

9. Plummer, M.; de Martel, C.; Vignat, J.; Ferlay, J.; Bray, F.; Franceschi, S. Global burden of cancers attributable to infections in 2012: A synthetic analysis. Lancet Glob. Health 2016, 4, e609-e616. [CrossRef]

10. Gallo, A.; Miceli, V.; Bulati, M.; Iannolo, G.; Contino, F.; Conaldi, P.G. Viral miRNAs as Active Players and Participants in Tumorigenesis. Cancers 2020, 12, 358. [CrossRef]

11. Zur Hausen, H. Papillomaviruses in the causation of human cancers-A brief historical account. Virology 2009, 384, 260-265. [CrossRef]

12. Moore, P.S.; Chang, Y. Why do viruses cause cancer? Highlights of the first century of human tumour virology. Nat. Rev. Cancer 2010, 10, 878-889. [CrossRef] [PubMed]

13. Krump, N.A.; You, J. Molecular mechanisms of viral oncogenesis in humans. Nat. Rev. Microbiol. 2018, 16, 684-698. [CrossRef]

14. Vojtechova, Z.; Tachezy, R. The Role of miRNAs in Virus-Mediated Oncogenesis. Int. J. Mol. Sci. 2018, 19, 1217. [CrossRef] [PubMed]

15. Song, S.; Gong, S.; Singh, P.; Lyu, J.; Bai, Y. The interaction between mitochondria and oncoviruses. Biochim. Biophys. Acta (BBA)-Mol. Basis Dis. 2018, 1864, 481-487. [CrossRef] [PubMed] 
16. Passos, A.M.; Granato, C.F.H. Cancer causing viruses and the role of laboratory medicine: Literature review and perspectives. J. Bras. Patol. Med. Lab. 2013, 49, 109-114. [CrossRef]

17. Klase, Z.; Kale, P.; Winograd, R.; Gupta, M.V.; Heydarian, M.; Berro, R.; McCaffrey, T.; Kashanchi, F. HIV-1 TAR element is processed by Dicer to yield a viral micro-RNA involved in chromatin remodeling of the viral LTR. BMC Mol. Biol. 2007, 8, 63. [CrossRef] [PubMed]

18. Wang, M.; Gu, B.; Chen, X.; Wang, Y.; Li, P.; Wang, K. The Function and Therapeutic Potential of Epstein-Barr Virus-Encoded MicroRNAs in Cancer. Mol. Ther.-Nucleic Acids 2019, 17, 657-668. [CrossRef] [PubMed]

19. Pfeffer, S.; Zavolan, M.; Grässer, F.A.; Chien, M.; Russo, J.J.; Ju, J.; John, B.; Enright, A.J.; Marks, D.; Sander, C.; et al. Identification of Virus-Encoded MicroRNAs. Science 2004, 304, 734-736. [CrossRef] [PubMed]

20. Lo, A.K.F.; To, K.F.; Lo, K.W.; Lung, R.W.M.; Hui, J.W.Y.; Liao, G.; Hayward, S.D. Modulation of LMP1 protein expression by EBV-encoded microRNAs. Proc. Natl. Acad. Sci. USA 2007, 104, 16164-16169. [CrossRef] [PubMed]

21. O'Bryan, S.; Dong, S.; Mathis, J.M.; Alahari, S.K. The roles of oncogenic miRNAs and their therapeutic importance in breast cancer. Eur. J. Cancer 2017, 72, 1-11. [CrossRef]

22. Maclachlan, N.J.; Dubovi, E.J. Fenner's Veterinary Virology; Elsevier Science: New York, NY, USA, 2010.

23. Nelemans, T.; Kikkert, M. Viral Innate Immune Evasion and the Pathogenesis of Emerging RNA Virus Infections. Viruses 2019, 11, 961. [CrossRef] [PubMed]

24. Grulich, A.E.; van Leeuwen, M.T.; Falster, M.O.; Vajdic, C.M. Incidence of cancers in people with HIV/AIDS compared with immunosuppressed transplant recipients: A meta-analysis. Lancet 2007, 370, 59-67. [CrossRef]

25. Xie, M.; Zhang, W.; Shu, M.D.; Xu, A.; Lenis, D.A.; DiMaio, D.; Steitz, J.A. The host Integrator complex acts in transcriptionindependent maturation of herpesvirus microRNA $3^{\prime}$ ends. Genes Dev. 2015, 29, 1552-1564. [CrossRef] [PubMed]

26. Cullen, B.R. MicroRNAs as mediators of viral evasion of the immune system. Nat. Immunol. 2013, 14, 205-210. [CrossRef] [PubMed]

27. Rowe, M.; Fitzsimmons, L.; Bell, A.I. Epstein-Barr virus and Burkitt lymphoma. Chin. J. Cancer 2014, 33, 609-619. [CrossRef] [PubMed]

28. De Re, V.; Caggiari, L.; De Zorzi, M.; Fanotto, V.; Miolo, G.; Puglisi, F.; Cannizzaro, R.; Canzonieri, V.; Steffan, A.; Farruggia, P.; et al. Epstein-Barr virus BART microRNAs in EBV-associated Hodgkin lymphoma and gastric cancer. Infect. Agents Cancer 2020, 15, 42. [CrossRef] [PubMed]

29. Wang, M.; Yu, F.; Wu, W.; Wang, Y.; Ding, H.; Qian, L. Epstein-Barr virus-encoded microRNAs as regulators in host immune responses. Int. J. Biol. Sci. 2018, 14, 565-576. [CrossRef] [PubMed]

30. Nachmani, D.; Stern-Ginossar, N.; Sarid, R.; Mandelboim, O. Diverse Herpesvirus MicroRNAs Target the Stress-Induced Immune Ligand MICB to Escape Recognition by Natural Killer Cells. Cell Host Microbe 2009, 5, 376-385. [CrossRef]

31. Pandya, D.; Mariani, M.; He, S.; Andreoli, M.; Spennato, M.; Dowell-Martino, C.; Fiedler, P.; Ferlini, C. Epstein-Barr Virus MicroRNA Expression Increases Aggressiveness of Solid Malignancies. PLoS ONE 2015, 10, e0136058. [CrossRef]

32. Wang, X.; Yang, X.; Zhang, C.; Wang, Y.; Cheng, T.; Duan, L.; Tong, Z.; Tan, S.; Zhang, H.; Saw, P.E.; et al. Tumor cell-intrinsic PD-1 receptor is a tumor suppressor and mediates resistance to PD-1 blockade therapy. Proc. Natl. Acad. Sci. USA 2020, 117, 6640-6650. [CrossRef] [PubMed]

33. Medina-Ortega, Á.P.; López-Valencia, D.; Mosquera-Monje, S.L.; Mora-Obando, D.L.; Dueñas-Cuéllar, R.A. Virus de Epstein-Barr y su relación con el desarrollo del cáncer. Iatreia 2017, 30, 131-145. [CrossRef]

34. Velapasamy, S.; Dawson, C.W.; Young, L.S.; Paterson, I.C.; Yap, L.F. The Dynamic Roles of TGF- $\beta$ Signalling in EBV-Associated Cancers. Cancers 2018, 10, 247. [CrossRef]

35. Ambrosio, M.R.; Navari, M.; Di Lisio, L.; Leon, E.A.; Onnis, A.; Gazaneo, S.; Mundo, L.; Ulivieri, C.; Gomez, G.; Lazzi, S.; et al. The Epstein Barr-encoded BART-6-3p microRNA affects regulation of cell growth and immuno response in Burkitt lymphoma. Infect. Agents Cancer 2014, 9, 12. [CrossRef]

36. Aquila, S.; Santoro, M.; Caputo, A.; Panno, M.L.; Pezzi, V.; De Amicis, F. The Tumor Suppressor PTEN as Molecular Switch Node Regulating Cell Metabolism and Autophagy: Implications in Immune System and Tumor Microenvironment. Cells 2020, 9, 1725. [CrossRef]

37. Xia, T.; O’Hara, A.; Araujo, I.; Barreto, J.; Carvalho, E.; Sapucaia, J.B.; Ramos, J.C.; Luz, E.; Pedroso, C.; Manrique, M.; et al. EBV MicroRNAs in Primary Lymphomas and Targeting of CXCL-11 by ebv-mir-BHRF1-3. Cancer Res. 2008, 68, 1436-1442. [CrossRef] [PubMed]

38. Sauty, A.; Colvin, R.A.; Wagner, L.; Rochat, S.; Spertini, F.; Luster, A.D. CXCR3 Internalization Following T CellEndothelial Cell Contact: Preferential Role of IFN-Inducible T Cell alpha Chemoattractant (CXCL11). J. Immunol. 2001, 167, 7084-7093. [CrossRef] [PubMed]

39. Mariggiò, G.; Koch, S.; Schulz, T.F. Kaposi sarcoma herpesvirus pathogenesis. Philos. Trans. R. Soc. B Biol. Sci. 2017, 372, 20160275. [CrossRef] [PubMed]

40. Piedade, D.; Azevedo-Pereira, J.M. The Role of microRNAs in the Pathogenesis of Herpesvirus Infection. Viruses 2016, 8, 156. [CrossRef]

41. Ahmad, I.; Valverde, A.; Siddiqui, H.; Schaller, S.; Naqvi, A.R. Viral MicroRNAs: Interfering the Interferon Signaling. Curr. Pharm. Des. 2020, 26, 446-454. [CrossRef]

42. Cousins, E.; Nicholas, J. Molecular Biology of Human Herpesvirus 8: Novel Functions and Virus-Host Interactions Implicated in Viral Pathogenesis and Replication. Recent Results Cancer Res. 2014, 193, 227-268.

43. Lin, X.; Liang, D.; He, Z.; Deng, Q.; Robertson, E.S.; Lan, K. miR-K12-7-5p encoded by Kaposi's sarcoma-associated herpesvirus stabilizes the latent state by targeting viral ORF50/RTA. PLoS ONE 2011, 6, 0016224. [CrossRef] [PubMed] 
44. Cai, X.; Lu, S.; Zhang, Z.; Gonzalez, C.M.; Damania, B.; Cullen, B.R. Kaposi's sarcoma-associated herpesvirus expresses an array of viral microRNAs in latently infected cells. Proc. Natl. Acad. Sci. USA 2005, 102, 5570-5575. [CrossRef] [PubMed]

45. Liang, D.; Gao, Y.; Lin, X.; He, Z.; Zhao, Q.; Deng, Q.; Lan, K. A human herpesvirus miRNA attenuates interferon signaling and contributes to maintenance of viral latency by targeting IKKE. Cell Res. 2011, 21, 793-806. [CrossRef] [PubMed]

46. Chaffer, C.L.; Weinberg, R.A. How Does Multistep Tumorigenesis Really Proceed? Cancer Discov. 2015, 5, 22-24. [CrossRef] [PubMed]

47. Cao, Y. Tumorigenesis as a process of gradual loss of original cell identity and gain of properties of neural precursor/progenitor cells. Cell Biosci. 2017, 7, 61. [CrossRef]

48. Shalini, S.; Dorstyn, L.; Dawar, S.; Kumar, S. Old, new and emerging functions of caspases. Cell Death Differ. 2015, 22, 526-539. [CrossRef] [PubMed]

49. Harold, C.; Cox, D.; Riley, K.J. Epstein-Barr viral microRNAs target caspase 3. Virol. J. 2016, 13, 145. [CrossRef] [PubMed]

50. Qiu, X.B.; Goldberg, A.L. The Membrane-associated Inhibitor of Apoptosis Protein, BRUCE/Apollon, Antagonizes Both the Precursor and Mature Forms of Smac and Caspase-9. J. Biol. Chem. 2005, 280, 174-182. [CrossRef] [PubMed]

51. Choi, H.; Lee, H.; Kim, S.R.; Gho, Y.S.; Lee, S.K. Epstein-Barr Virus-Encoded MicroRNA BART15-3p Promotes Cell Apoptosis Partially by Targeting BRUCE. J. Virol. 2013, 87, 8135-8144. [CrossRef] [PubMed]

52. Li, Y.; Deutzmann, A.; Felsher, D.W. BIM-mediated apoptosis and oncogene addiction. Aging 2016, 8, 1834-1835. [CrossRef] [PubMed]

53. Li, M. The role of P53 up-regulated modulator of apoptosis (PUMA) in ovarian development, cardiovascular and neurodegenerative diseases. Apoptosis 2021, 26, 235-247. [CrossRef] [PubMed]

54. Choy, E.Y.W.; Siu, K.L.; Kok, K.H.; Lung, R.W.M.; Tsang, C.M.; To, K.F.; Kwong, D.L.W.; Tsao, S.W.; Jin, D.Y. An Epstein-Barr virus-encoded microRNA targets PUMA to promote host cell survival. J. Exp. Med. 2008, 205, 2551-2560. [CrossRef] [PubMed]

55. Marquitz, A.R.; Mathur, A.; Nam, C.S.; Raab-Traub, N. The Epstein-Barr Virus BART microRNAs target the pro-apoptotic protein Bim. Virology 2011, 412, 392-400. [CrossRef] [PubMed]

56. Kim, H.; Choi, H.; Lee, S.K. Epstein-Barr virus miR-BART20-5p regulates cell proliferation and apoptosis by targeting BAD. Cancer Lett. 2015, 356(2 Pt B), 733-742. [CrossRef] [PubMed]

57. Curado, S.; Ober, E.A.; Walsh, S.; Cortes-Hernandez, P.; Verkade, H.; Koehler, C.M.; Stainier, D.Y.R. The mitochondrial import gene tomm22 is specifically required for hepatocyte survival and provides a liver regeneration model. Dis. Model. Mech. 2010, 3 , 486-495. [CrossRef]

58. Dölken, L.; Malterer, G.; Erhard, F.; Kothe, S.; Friedel, C.C.; Suffert, G.; Marcinowski, L.; Motsch, N.; Barth, S.; Beitzinger, M.; et al. Systematic Analysis of Viral and Cellular MicroRNA Targets in Cells Latently Infected with Human $\gamma$-Herpesviruses by RISC Immunoprecipitation Assay. Cell Host Microbe 2010, 7, 324-334. [CrossRef]

59. Malkesman, O.; Austin, D.R.; Tragon, T.; Henter, I.D.; Reed, J.C.; Pellecchia, M.; Chen, G.; Manji, H.K. Targeting the BH3-interacting domain death agonist to develop mechanistically unique antidepressants. Mol. Psychiatry 2012, 17, 770-780. [CrossRef] [PubMed]

60. Shinozaki-Ushiku, A.; Kunita, A.; Isogai, M.; Hibiya, T.; Ushiku, T.; Takada, K.; Fukayama, M. Profiling of Virus-Encoded MicroRNAs in Epstein-Barr Virus-Associated Gastric Carcinoma and Their Roles in Gastric Carcinogenesis. J. Virol. 2015, 89, 5581-5591. [CrossRef] [PubMed]

61. Choi, Y.B.; Shembade, N.; Parvatiyar, K.; Balachandran, S.; Harhaj, E.W. TAX1BP1 Restrains Virus-Induced Apoptosis by Facilitating Itch-Mediated Degradation of the Mitochondrial Adaptor MAVS. Mol. Cell Biol. 2017, 37, e00422-16. [CrossRef] [PubMed]

62. Choi, H.; Lee, S.K. TAX1BP1 downregulation by EBV-miR-BART15-3p enhances chemosensitivity of gastric cancer cells to 5-FU. Arch. Virol. 2017, 162, 369-377. [CrossRef] [PubMed]

63. Liu, S.; Chen, S.; Zeng, J. TGF- $\beta$ signaling: A complex role in tumorigenesis (Review). Mol. Med. Rep. 2018, 17, 699-704. [CrossRef] [PubMed]

64. Zhan, T.; Rindtorff, N.; Boutros, M. Wnt signaling in cancer. Oncogene 2017, 36, 1461-1473. [CrossRef]

65. Wan, X.X.; Yi, H.; Qu, J.; He, Q.; Xiao, Z. Integrated analysis of the differential cellular and EBV miRNA expression profiles in microdissected nasopharyngeal carcinoma and non-cancerous nasopharyngeal tissues. Oncol. Rep. 2015, 34, 2585-2601. [CrossRef] [PubMed]

66. Grundhoff, A.; Sullivan, C.S. Virus-encoded microRNAs. Virology 2011, 411, 325-343. [CrossRef] [PubMed]

67. Ganem, D. KSHV and the pathogenesis of Kaposi sarcoma: Listening to human biology and medicine. J. Clin. Investig. 2010, 120, 939-949. [CrossRef] [PubMed]

68. Suffert, G.; Malterer, G.; Hausser, J.; Viiliäinen, J.; Fender, A.; Contrant, M.; Ivacevic, T.; Benes, V.; Gros, F.; Voinnet, O.; et al. Kaposi's sarcoma herpesvirus microRNAs target caspase 3 and regulate apoptosis. PLoS Pathog. 2011, 7, e1002405. [CrossRef]

69. Abend, J.R.; Uldrick, T.; Ziegelbauer, J.M. Regulation of tumor necrosis factor-like weak inducer of apoptosis receptor protein (TWEAKR) expression by Kaposi's sarcoma-associated herpesvirus microRNA prevents TWEAK-induced apoptosis and inflammatory cytokine expression. J. Virol. 2010, 84, 12139-12151. [CrossRef] [PubMed]

70. Jiang, T.; Liu, B.; Wu, D.; Zhang, F. BCLAF1 induces cisplatin resistance in lung cancer cells. Oncol. Lett. 2020, 20, 227. [CrossRef] [PubMed]

71. Forte, E.; Raja, A.N.; Shamulailatpam, P.; Manzano, M.; Schipma, M.J.; Casey, J.L.; Gottwein, E. MicroRNA-Mediated Transformation by the Kaposi's Sarcoma-Associated Herpesvirus Kaposin Locus. J. Virol. 2015, 89, 2333-2341. [CrossRef]

72. Xiao, B.D.; Zhao, Y.J.; Jia, X.Y.; Wu, J.; Wang, Y.G.; Huang, F. Multifaceted p21 in carcinogenesis, stemness of tumor and tumor therapy. World J. Stem. Cells 2020, 12, 481-487. [CrossRef] [PubMed] 
73. Gottwein, E.; Cullen, B.R. A Human Herpesvirus MicroRNA Inhibits p21 Expression and Attenuates p21-Mediated Cell Cycle Arrest. J. Virol. 2010, 84, 5229-5237. [CrossRef] [PubMed]

74. Ziegelbauer, J.M. Functions of Kaposi's sarcoma-associated herpesvirus microRNAs. Biochim. Biophys. Acta 2011, 1809, 623-630. [CrossRef]

75. Al-Hilu, S.A.; Al-Shujairi, W.H. Dual Role of Bacteria in Carcinoma: Stimulation and Inhibition. Int. J. Microbiol. 2020, 2020, 4639761. [CrossRef]

76. Zella, D.; Gallo, R. Viruses and Bacteria Associated with Cancer: An Overview. Viruses 2021, 13, 1039. [CrossRef] [PubMed]

77. Goodman, B.; Gardner, H. The microbiome and cancer. J. Pathol. 2018, 244, 667-676. [CrossRef] [PubMed]

78. Tran, N.; Hutvagner, G. Biogenesis and the regulation of the maturation of miRNAs. Essays Biochem. 2013, 54, 17-28. [CrossRef] [PubMed]

79. Bloch, S.; Wegrzyn, A.; Wegrzyn, G.; Nejman-Faleńczyk, B. Smaller-sRNAs and MicroRNAs in the Regulation of Toxin Gene Expression in Prokaryotic Cells: A. Mini-Review. Toxins 2017, 9, 181. [CrossRef] [PubMed]

80. Furuse, Y.; Finethy, R.; Saka, H.A.; Xet-Mull, A.M.; Sisk, D.M.; Smith, K.L.J.; Lee, S.; Coers, J.; Valdivia, R.H.; Tobin, D.; et al. Search for MicroRNAs Expressed by Intracellular Bacterial Pathogens in Infected Mammalian Cells. PLoS ONE 2014, 9, e106434. [CrossRef] [PubMed]

81. Kang, S.M.; Choi, J.W.; Lee, Y.; Hong, S.H.; Lee, H.J. Identification of microRNA-size, small RNAs in Escherichia coli. Curr. Microbiol. 2013, 67, 609-613. [CrossRef] [PubMed]

82. Lee, H.J.; Hong, S.H. Analysis of microRNA-size, small RNAs in Streptococcus mutans by deep sequencing. FEMS Microbiol. Lett. 2012, 326, 131-136. [CrossRef] [PubMed]

83. Storz, G.; Vogel, J.; Wassarman, K.M. Regulation by Small RNAs in Bacteria: Expanding Frontiers. Mol. Cell 2011, 43, 880-891. [CrossRef]

84. González Plaza, J.J. Small RNAs as Fundamental Players in the Transference of Information During Bacterial Infectious Diseases. Front. Mol. Biosci. 2020, 7, 101. [CrossRef]

85. Podkaminski, D; Vogel, J. Small RNAs promote mRNA stability to activate the synthesis of virulence factors. Mol. Microbiol. 2010, 78, 1327-1331. [CrossRef]

86. Wassarman, K.M. Small RNAs in Bacteria: Diverse Regulators of Gene Expression in Response to Environmental Changes. Cell 2002, 109, 141-144. [CrossRef]

87. Morita, T.; Aiba, H. RNase E action at a distance: Degradation of target mRNAs mediated by an Hfq-binding small RNA in bacteria. Genes Dev. 2011, 25, 294-298. [CrossRef]

88. Hatta, M.; Hanif, E.M.; Chin, S.F.; Neoh, H.M. Pathogens and Carcinogenesis: A Review. Biology 2021, 10, 533. [CrossRef]

89. Kinoshita-Daitoku, R.; Kiga, K.; Miyakoshi, M.; Otsubo, R.; Ogura, Y.; Sanada, T.; Bo, Z.; Phuoc, T.V.; Okano, T.; Iida, T.; et al. A bacterial small RNA regulates the adaptation of Helicobacter pylori to the host environment. Nat. Commun. 2021, 12, 2085. [CrossRef] [PubMed]

90. Du, J.; Zhang, W.; Li, X.; Li, Y. Bioinformatics analysis of small RNAs in Helicobacter pylori and the role of NAT-67 under tinidazole treatment. Mol. Med. Rep. 2020, 22, 1227-1234. [CrossRef]

91. Pernitzsch, S.R.; Tirier, S.M.; Beier, D.; Sharma, C.M. A variable homopolymeric G-repeat defines small RNA-mediated posttranscriptional regulation of a chemotaxis receptor in Helicobacter pylori. Proc. Natl. Acad. Sci. USA 2014, 111, E501-E510. [CrossRef]

92. Huang, J.Y.; Sweeney, E.G.; Sigal, M.; Zhang, H.C.; Remington, S.J.; Cantrell, M.A.; Kuo, C.J.; Guillemin, K.; Amieva, M.R. Chemodetection and Destruction of Host Urea Allows Helicobacter pylori to Locate the Epithelium. Cell Host Microbe 2015, 18, 147-156. [CrossRef] [PubMed]

93. Hanyu, H.; Engevik, K.A.; Matthis, A.L.; Ottemann, K.M.; Montrose, M.H.; Aihara, E. Helicobacter pylori Uses the TlpB Receptor to Sense Sites of Gastric Injury. Infect. Immun. 2019, 87, e00202-19. [CrossRef] [PubMed]

94. Noto, J.M.; Peek, R.M., Jr. The Helicobacter pylori cag Pathogenicity Island. Methods Mol. Biol. 2012, 921, 41-50. [PubMed]

95. Vannini, A.; Roncarati, D.; Danielli, A. The cag-pathogenicity island encoded CncR1 sRNA oppositely modulates Helicobacter pylori motility and adhesion to host cells. Cell. Mol. life Sci. CMLS 2016, 73, 3151-3168. [CrossRef]

96. Eisenbart, S.K.; Alzheimer, M.; Pernitzsch, S.R.; Dietrich, S.; Stahl, S.; Sharma, C.M. A Repeat-Associated Small RNA Controls the Major Virulence Factors of Helicobacter pylori. Mol. Cell 2020, 80, 210-226. [CrossRef]

97. Phillips, Z.N.; Tram, G.; Seib, K.; Atack, J.M. Phase-variable bacterial loci: How bacteria gamble to maximise fitness in changing environments. Biochem. Soc. Trans. 2019, 47, 1131-1141. [CrossRef] [PubMed]

98. Zhang, H.; Zhang, Y.; Song, Z.; Li, R.; Ruan, H.; Liu, Q.; Huang, X. sncRNAs packaged by Helicobacter pylori outer membrane vesicles attenuate IL-8 secretion in human cells. Int. J. Med. Microbiol. 2020, 310, 151356. [CrossRef] [PubMed]

99. Wen, Y.; Feng, J.; Scott, D.R.; Marcus, E.A.; Sachs, G. A cis-encoded antisense small RNA regulated by the HP0165-HP0166 two-component system controls expression of ureB in Helicobacter pylori. J. Bacteriol. 2011, 193, 40-51. [CrossRef] [PubMed]

100. Zhao, H.; Wu, Y.; Xu, Z.; Ma, R.; Ding, Y.; Bai, X.; Rong, Q.; Zhang, Y.; Li, B.; Ji, X. Mechanistic Insight Into the Interaction Between Helicobacter pylori Urease Subunit $\alpha$ and Its Molecular Chaperone Hsp60. Front. Microbiol. 2019, 10, 153. [CrossRef]

101. Van Vliet, A.H.M.; Poppelaars, S.W.; Davies, B.J.; Stoof, J.; Bereswill, S.; Kist, M.; Penn, C.W.; Kuipers, E.J.; Kusters, J.G. NikR Mediates Nickel-Responsive Transcriptional Induction of Urease Expression in Helicobacter pylori. Infect. Immun. 2002, 70, 2846-2852. [CrossRef] 
102. Wen, Y.; Feng, J.; Scott, D.R.; Marcus, E.A.; Sachs, G. The HP0165-HP0166 Two-Component System (ArsRS) Regulates AcidInduced Expression of HP1186\#土-Carbonic Anhydrase in Helicobacter pylori by Activating the pH-Dependent Promoter. J. Bacteriol. 2007, 189, 2426-2434. [PubMed]

103. Xiao, B.; Li, W.; Guo, G.; Li, B.S.; Liu, Z.; Tang, B.; Mao, X.H.; Zou, Q.M. Screening and identification of natural antisense transcripts in Helicobacter pylori by a novel approach based on RNase I protection assay. Mol. Biol. Rep. 2009, 36, 1853-1858. [CrossRef] [PubMed]

104. Mjelle, R.; Sjursen, W.; Thommesen, L.; Sætrom, P.; Hofsli, E. Small RNA expression from viruses, bacteria and human miRNAs in colon cancer tissue and its association with microsatellite instability and tumor location. BMC Cancer 2019, 19, 161. [CrossRef]

105. Hashemi, G.N.; Heidarzadeh, S.; Jahangiri, S.; Farhood, B.; Mortezaee, K.; Khanlarkhani, N.; Negahdari, B. Fusobacterium nucleatum and colorectal cancer: A mechanistic overview. J. Cell Physiol. 2020, 234, 2337-2344. [CrossRef]

106. Lee, W.H.; Chen, K.P.; Wang, K.; Huang, H.C.; Juan, H.F. Characterizing the cancer-associated microbiome with small RNA sequencing data. Biochem. Biophys. Res. Commun. 2019, 522, 776-782. [CrossRef]

107. Tarallo, S.; Ferrero, G.; Gallo, G.; Francavilla, A.; Clerico, G.; Luc, A.R.; Manghi, P.; Thomas, A.M.; Vineis, P.; Segata, N.; et al. Altered Fecal Small RNA Profiles in Colorectal Cancer Reflect Gut Microbiome Composition in Stool Samples. mSystems 2019, 4, e00289-19. [CrossRef]

108. Parise, M.T.D.; Parise, D.; Aburjaile, F.F.; Gomide, A.C.P.; Kato, R.B.; Raden, M.; Backofen, R.; Azevedo, V.A.D.C.; Baumbach, J. An Integrated Database of Small RNAs and Their Interplay With Transcriptional Gene Regulatory Networks in Corynebacteria. Front. Microbiol. 2021, 12, 1540. [CrossRef]

109. Han, K.; Lory, S. Toward a Comprehensive Analysis of Posttranscriptional Regulatory Networks: A New Tool for the Identification of Small RNA Regulators of Specific mRNAs. Mbio 2021, 12, e03608-20. [CrossRef]

110. Henderson, C.A.; Vincent, H.A.; Callaghan, A.J. Reprogramming Gene Expression by Targeting RNA-Based Interactions: A Novel Pipeline Utilizing RNA Array Technology. ACS Synth. Biol. 2021, 10, 1847-1858. [CrossRef]

111. Lee, Y.J.; Moon, T.S. Design rules of synthetic non-coding RNAs in bacteria. Methods 2018, 143, 58-69. [CrossRef]

112. Dersch, P.; Khan, M.A.; Mühlen, S.; Görke, B. Roles of Regulatory RNAs for Antibiotic Resistance in Bacteria and Their Potential Value as Novel Drug Targets. Front. Microbiol. 2017, 8, 803. [CrossRef]

113. Le Huyen, K.B.; Gonzalez, C.D.; Pascreau, G.; Bordeau, V.; Cattoir, V.; Liu, W.; Bouloc, P.; Felden, B.; Chabelskaya, S. A small regulatory RNA alters Staphylococcus aureus virulence by titrating RNAIII activity. Nucleic Acids Res. 2021, 49, 10644-10656. [CrossRef]

114. Nagakubo, T.; Nomura, N.; Toyofuku, M. Cracking Open Bacterial Membrane Vesicles. Front. Microbiol. 2019, 10, 3026. [CrossRef]

115. Cecil, J.D.; Sirisaengtaksin, N.; O’Brien-Simpson, N.; Krachler, A.M. Outer Membrane Vesicle-Host Cell Interactions. Microbiol. Spectr. 2019, 7, 201-214. [CrossRef]

116. Li, M.; Zhou, H.; Yang, C.; Wu, Y.; Zhou, X.; Liu, H.; Wang, Y. Bacterial outer membrane vesicles as a platform for biomedical applications: An update. J. Control. Release 2020, 323, 253-268. [CrossRef]

117. Ismail, S.; Hampton, M.B.; Keenan, J.I. Helicobacter pylori outer membrane vesicles modulate proliferation and interleukin-8 production by gastric epithelial cells. Infect Immun. 2003, 71, 5670-5675. [CrossRef] [PubMed]

118. Chmiela, M.; Walczak, N.; Rudnicka, K. Helicobacter pylori outer membrane vesicles involvement in the infection development and Helicobacter pylori-related diseases. J. Biomed. Sci. 2018, 25, 78. [CrossRef]

119. González, M.F.; Díaz, P.; Sandoval-Bórquez, A.; Herrera, D.; Quest, A.F. Helicobacter pylori Outer Membrane Vesicles and Extracellular Vesicles from Helicobacter pylori-Infected Cells in Gastric Disease Development. Int. J. Mol. Sci. 2021, 22, 4823. [CrossRef]

120. Mishra, R.; Kumar, A.; Ingle, H.; Kumar, H. The Interplay Between Viral-Derived miRNAs and Host Immunity During Infection. Front. Immunol. 2020, 10, 3079. [CrossRef]

121. Gomes, C.; Cho, J.H.; E Hood, L.; Franco, O.L.; Pereira, R.W.D.; Wang, K. A Review of Computational Tools in microRNA Discovery. Front. Genet. 2013, 4, 81. [CrossRef]

122. Loganantharaj, R.; Randall, T.A. The Limitations of Existing Approaches in Improving MicroRNA Target Prediction Accuracy. Methods Mol. Biol. 2017, 1617, 133-158.

123. Benesova, S.; Kubista, M.; Valihrach, L. Small RNA-Sequencing: Approaches and Considerations for miRNA Analysis. Diagnostics 2021, 11, 964. [CrossRef]

124. Whitley, S.K.; Horne, W.T.; Kolls, J.K. Research Techniques Made Simple: Methodology and Clinical Applications of RNA Sequencing. J. Investig. Dermatol. 2016, 136, e77-e82. [CrossRef]

125. Tarang, S.; Weston, M.D. Macros in microRNA target identification: A comparative analysis of in silico, in vitro, and in vivo approaches to microRNA target identification. RNA Biol. 2014, 11, 324-333. [CrossRef]

126. Xiong, Z.Q.; Lv, Z.X.; Song, X.; Liu, X.X.; Xia, Y.J.; Ai, L.Z. Recent Research Advances in Small Regulatory RNAs in Streptococcus. Curr. Microbiol. 2021, 78, 2231-2241. [CrossRef]

127. Arrieta-Ortiz, M.L.; Hafemeister, C.; Shuster, B.; Baliga, N.S.; Bonneau, R.; Eichenberger, P. Inference of Bacterial Small RNA Regulatory Networks and Integration with Transcription Factor-Driven Regulatory Networks. mSystems 2020, 5, e00057-20. [CrossRef]

128. Brennan, C.A.; Garrett, W.S. Fusobacterium nucleatum-Symbiont, opportunist and oncobacterium. Nat. Rev. Microbiol. 2019, 17, 156-166. [CrossRef] 